論文・Paper

\title{
Phase Equilibria in the System $\mathrm{Nb}-\mathrm{N}$ at Temperatures $1300^{\circ}-1700^{\circ} \mathrm{C}$
}

\author{
Nobuo KIEDA, Nobuyasu MIZUTANI and Masanori KATO \\ (Department of Inorganic Materials, Faculty of Engineering, \\ 2-12-1, O-okayama, Meguro-ku, 152
}

\begin{abstract}
Phase equilibria in the system $\mathrm{Nb}-\mathrm{N}$ was investigated at temperatures $1300^{\circ}-1700^{\circ} \mathrm{C}$ under $P_{\mathrm{N}_{2}} 10^{-2}$ $1 \mathrm{~atm}$ by chemical analysis and $\mathrm{X}$-ray diffraction of quenched sample and TG technique. Four nitride phases $\left(\beta-\mathrm{Nb}_{2} \mathrm{~N}, \gamma-\mathrm{Nb}_{4} \mathrm{~N}_{3}, \delta\right.$ - $\mathrm{NbN}$ and $\left.\varepsilon-\mathrm{NbN}\right)$ were present and $\gamma$ - and $\delta$-phase had a wide homogeneity range at room temperature: $\mathrm{NbN}_{0.71}-\mathrm{NbN}_{0.84}$ and $\mathrm{NbN}_{0.84}-\mathrm{NbN}_{0.92}$, respectively. The nitrogen partial pressure-temperature-composition diagram $\left(P_{\mathrm{N}_{2}}-T-x\right.$ diagram $)$ was constructed and used to determine the phase boundaries between nitride phases. The phase boundary between $\gamma$ - and $\delta$-phase shifted to lower nitrogen content with increasing temperature and $\gamma$-phase transformed to $\delta$-phase at temperatures between $1500^{\circ}-1600^{\circ} \mathrm{C}$. Since there was no break on the $P_{\mathrm{N}_{2}}-x$ isotherms at the transformation point, $\gamma \rightleftarrows \delta$ transformation is not of first order probably. A portion of phase diagram of the system $\mathrm{Nb}-\mathrm{N}$ is proposed.

[Received August 1, 1985]
\end{abstract}

\section{$\mathbf{N b}-\mathbf{N}$ 系の相平衡}

\author{
木枝暢夫 · 水谷惟恭 ·加藤誠軌
}

(東京工業大学 工学部 無機材料工学科)

\begin{abstract}
$\mathrm{Nb}-\mathrm{N}$ 系の相平衡を, 温度 $1300^{\circ} \sim 1700^{\circ} \mathrm{C}$, 窒素分圧 $10^{-2}-1 \mathrm{~atm}$ の範囲について, 急冷試料の化 学分析とX線回折, 及び熱天科法を用いて研究した。生成した窒化物相は, $\beta-\mathrm{Nb}_{2} \mathrm{~N}, \gamma-\mathrm{Nb}_{4} \mathrm{~N}_{3}, \delta$ $\mathrm{NbN}, \varepsilon-\mathrm{NbN}$ の 4 相である.このなかで, $\gamma$ 相と $\delta$ 相が大きな不定比性を示し, 均一領域はそれ ぞれ $\mathrm{NbN}_{0.71}-\mathrm{NbN}_{0.84}$ 及び $\mathrm{NbN}_{0.84}-\mathrm{NbN}_{0.92}$ であった. 高温における各相の相境界を窒素分圧-温度組成図 $\left(P_{\mathrm{N}_{2}}-T-x\right.$ 図) を用いて検討し，次のような結論を得た。（1） $\gamma$ 相と $\delta$ 相の相境界は温度 が高くなるほど窒素量の少ない側へと移り， $1500^{\circ} \mathrm{C}$ と $1600^{\circ} \mathrm{C}$ の間で， $\gamma$ 相は $\delta$ 相へと転移する, ( 2) $\gamma \rightleftarrows \delta$ 転移の際, $P_{\mathrm{N}_{2}}-T-x$ 図の等温線に不連続が生じないことから，この転移の次数は 1 次 でないと考えられる，以上の結果に基づき， Nb-N 系の状態図を作成した。（1985 年 8 月 1 日受付）
\end{abstract}

Key-words : Niobium nitride, $P_{\mathrm{N}_{2}}-T-x$ diagram, Phase diagram

\section{Introduction}

The phase relationship of the niobium-nitrogen system is very complex, because many phases having.wide homogeneity ranges are present. The previous phase studies were carried out by chemical analysis and X-ray diffraction of quenched sample ${ }^{1-5)}$, furthermore, the crystal structures of the phases were investigated precisely by electron diffraction of thin film ${ }^{6 /-8)}$ or neutron diffraction of single crystal ${ }^{9)-11}$. According to these works, seven nitride phases $\left(\beta-\mathrm{Nb}_{2} \mathrm{~N}, \gamma-\mathrm{Nb}_{4} \mathrm{~N}_{3}, \delta-\mathrm{NbN}\right.$, $\delta^{\prime}-\mathrm{NbN}, \varepsilon-\mathrm{NbN}, \mathrm{Nb}_{5} \mathrm{~N}_{6}$ and $\left.\mathrm{Nb}_{4} \mathrm{~N}_{5}\right)$ and a terminal solid solution $\left(\alpha-\mathrm{NbN}_{x}\right)$ have been found in this system. The phases $\mathrm{Nb}_{5} \mathrm{~N}_{6}$ and $\mathrm{Nb}_{4} \mathrm{~N}_{5}$ were obtained only in the form of thin film prepared by the reaction between evaporated niobium film and ammonia $^{6 /, 7)}$ or by chemical vapor deposition ${ }^{8)}$. $\delta$ - $\mathrm{NbN}$ is high temperature phase and stable above $\sim 1270^{\circ} \mathrm{C} . \delta^{\prime}-\mathrm{NbN}$ appears as a transient phase during the transformation $\delta \rightarrow \varepsilon$. The homogenei- 
ty ranges and the crystal structures of these nitrides except $\mathrm{Nb}_{5} \mathrm{~N}_{6}$ and $\mathrm{Nb}_{4} \mathrm{~N}_{5}$ are summarized in Table 1.

Though many investigations about the phases are present, the phase diagram of this system ${ }^{12)}$ is incomplete. One of the reason is lack of experiments with nitrogen pressure control. Pressure-temperature-composition diagram $(P-T-x$ diagram) is effective for examining phase relations of a metal-gas system containing nonstoichiometric compounds. In $P-T-x$ diagram, knee or break of the isotherm or isobar show the boundary between different phases. Nevertheless, almost the previous works were carried out without nitrogen pressure control and $P_{\mathrm{N}_{2}}-T$ $x$ diagram has been reported only by Gebhardt et al. in the region up to 30 at $\% \mathrm{~N}^{13}$.

Nitrogen partial pressure-temperature-composition relations of niobium-nitrogen system was studied for $T=1300^{\circ}-1700^{\circ} \mathrm{C}$ and $P_{\mathrm{N}_{2}}=10^{-2}$ $1 \mathrm{~atm}$ both by chemical analysis of quenched samples and by $\mathrm{TG}$ technique. The presence of $\beta$ - $\mathrm{Nb}_{2} \mathrm{~N}, \quad \gamma-\mathrm{Nb}_{4} \mathrm{~N}_{3}, \delta$ - $\mathrm{NbN}$ and $\varepsilon-\mathrm{NbN}$ were identified by X-ray analysis. The phase boundaries between these four phases were discussed and the phase diagram of the system $\mathrm{Nb}-\mathrm{N}$ was proposed.

\section{Experimental}

\subsection{Quench method}

Most of experimental procedure was described in previous paper concerning vanadium mononitride $^{14)}$.

A niobium powder (Soekawa Chemical Co. Ltd., -325 mesh) was used as a starting material. The analysis of the powder is given in Table 2. The metal powder was nitrided in a
$\mathrm{N}_{2}-\mathrm{H}_{2}$ mixed gas at $1300^{\circ} \mathrm{C}$ or hydrided in a $\mathrm{H}_{2}-\mathrm{Ar}$ mixed gas at $350^{\circ} \mathrm{C}$. The nitrided powder consisted of $\gamma-\mathrm{Nb}_{4} \mathrm{~N}_{3}$ and $\varepsilon-\mathrm{NbN}$ and had the composition of about $\mathrm{NbN}_{0.95}$. The hydrided powder consisted of niobium hydride (JCPDS 7$\left.263 ; \mathrm{NbH}_{0.89}\right)$. These powders were pulverized using an alumina mortar and pestle and used in the following equilibrium experiment.

About $2 \mathrm{~g}$ of the nitride or hydride powder was annealed in a vertical tube furnace at $1300^{\circ}$ $1700^{\circ} \mathrm{C}$ under $P_{\mathrm{N}_{2}} 10^{-2}-1$ atm for $20-100$ hours, and quenched to room temperature very rapidly. For the experiments at $1500^{\circ}-1700^{\circ} \mathrm{C}$, the furnace with a spiral carbon heating element and alumina muffle tube was used and the temperature of the sample was measured by $\mathrm{W} \cdot \operatorname{Re} 5 \%-\mathrm{W} \cdot \operatorname{Re} 26 \%$ thermocouple placed in the muffle tube. For the experiment at $1300^{\circ}-1500^{\circ} \mathrm{C}$, the same furnace that had been used in the previous work ${ }^{14)}$ was used. Nitrogen partial pressure was established by mixing $\mathrm{N}_{2}$ and $\mathrm{H}_{2}$ which were purified by passing them through nitrided titanium sponges heated at $850^{\circ} \mathrm{C}$.

The nitrogen content of the samples was determined using the Dumas method. The niobium content was determined gravimetrically by oxidizing a weighed specimen at $1000^{\circ} \mathrm{C}$ in air. The total nitrogen and niobium contents were found to be between 99.7 and $100.0 \mathrm{wt} \%$ in most cases. The residue was assumed to be oxygen.

An X-ray powder diffractometer (Philips PW 1700) was used for phase identification and lattice parameter measurement.

\subsection{TG method}

The thermogravimetric measurement was made using a Shimadzu TGA-30 thermobalance. The
Table 1. Homogeneity range and crystal structure of niobium nitrides.

\begin{tabular}{|c|c|c|c|c|c|}
\hline phase & $\beta-\mathrm{Nb}_{2} \mathrm{~N}$ & $\gamma-\mathrm{Nb}_{4}{ }^{\mathrm{N}} 3$ & $\delta-\mathrm{NbN}$ & $\delta^{\prime}-\mathrm{NbN}$ & $\varepsilon-\mathrm{NbN}$ \\
\hline $\begin{array}{c}\text { homogeneity } \\
\text { range, } \\
\mathrm{N} / \mathrm{Nb}=\end{array}$ & $0.40-0.50$ & $0.75-0.79$ & $\begin{array}{r}0.88-0.98 \\
\left.(-1.06)^{1}\right)\end{array}$ & $\sim 0.95$ & $\sim 1.00$ \\
\hline $\begin{array}{l}\text { crystal } \\
\text { structure }\end{array}$ & $\varepsilon-\mathrm{Fe}_{2} \mathrm{~N}$ & $\begin{array}{c}\text { distorted } \\
\text { NaCl }\end{array}$ & $\mathrm{NaCl}$ & anti-NîAs & $\operatorname{TiP}^{21}$ \\
\hline $\begin{array}{l}\text { niobium } \\
\text { sublattice }\end{array}$ & $\begin{array}{c}\text { hcp } \\
(A B, A B)\end{array}$ & $\begin{array}{c}\text { fct } \\
(A B C, A B C)\end{array}$ & $\begin{array}{c}f C C \\
(A B C, A B C)\end{array}$ & $\begin{array}{c}\text { hcp } \\
(\mathrm{AB}, \mathrm{AB})\end{array}$ & $\begin{array}{c}\text { hex } \\
(\mathrm{AABB}, \mathrm{AABB})\end{array}$ \\
\hline $\begin{array}{l}\text { nitrogen } \\
\text { site }\end{array}$ & $\begin{array}{r}\text { octahedral } \\
\text { (ordered) }\end{array}$ & $\begin{array}{r}\text { octahedral } \\
\text { (ordered) }\end{array}$ & $\begin{array}{l}\text { octahedral } \\
\text { (random) }\end{array}$ & octahedral & $\begin{array}{l}\text { octahedral } \\
\text { tri. prism }\end{array}$ \\
\hline $\begin{array}{c}\text { lattice } \\
\text { parameter } \\
(\AA)\end{array}$ & $\begin{array}{l}\mathrm{a}=3.056 \\
\mathrm{c}=4.954 \\
\left(\mathrm{NbN}_{0.40}\right) \\
\mathrm{a}=3.052 \\
\mathrm{c}=4.995 \\
\left(\mathrm{NbN}_{0.50}\right)\end{array}$ & $\begin{aligned} a & =4.386 \\
c & =4.311 \\
& \left(\mathrm{NbN}_{0} .75\right) \\
\mathrm{a} & =4.386 \\
\mathrm{c} & =4.335 \\
& \left(\mathrm{NbN}_{0} .80\right)\end{aligned}$ & $\begin{array}{l}a=4.382 \\
\left(\mathrm{NbN}_{0} .88\right) \\
a=4.392 \\
\left(\mathrm{NbN}_{0} .98\right)\end{array}$ & $\begin{array}{l}\mathrm{a}=2.94 \\
\mathrm{C}=5.46 \\
\quad\left(\mathrm{NbN}_{0.95}\right)\end{array}$ & $\begin{array}{l}\mathrm{a}=2.956 \\
\mathrm{c}=11.275 \\
\left(\mathrm{NbN}_{1} .00\right)\end{array}$ \\
\hline
\end{tabular}
sample was annealed at $1300^{\circ}$ or $1350^{\circ} \mathrm{C}$ under $P_{\mathrm{N}_{2}} 10^{-2}-1 \mathrm{~atm}$ with monitoring the sample weight. When equilibrium was reached,

Table 2. Chemical analysis of niobium powder.

\begin{tabular}{|c|c|}
\hline element & content(ppm) \\
\hline $\mathrm{Ta}$ & 615 \\
$\mathrm{Fe}$ & 15 \\
$\mathrm{~B}, \mathrm{Al}, \mathrm{Si}, \mathrm{Ca}$, & \\
$\mathrm{Ti}, \mathrm{Cr}, \mathrm{Mn}, \mathrm{Ni}$, & $<10$ \\
$\mathrm{Cu}, \mathrm{Zr}, \mathrm{Mo}, \mathrm{Sn}$, & \\
$\mathrm{Hg}$ & $<5$ \\
$\mathrm{Zn}, \mathrm{As}, \mathrm{Te}, \mathrm{Bi}$ & $<1$ \\
$\mathrm{~Pb}$ & \\
\hline
\end{tabular}


the weight became constant and the composition of the smple could be determined from this weight. Then $P_{\mathrm{N}_{2}}$ was changed stepwise and corresponding weight change was measured.

A niobium powder was also used as a starting material. About $2 \mathrm{~g}$ of this powder was placed in an alumina cruicible, it was then hanged from the balance by molybdenum hooks and was located in an alumina tube connected to the balance chamber. A vertical tube furnace with a spiral $\mathrm{SiC}$ heating element was used to heat the sample. The temperature of the sample was measured by $\mathrm{Pt}-\mathrm{Pt}$ $\mathrm{Rh} 13 \%$ thermocouple placed right below it.

The nitrogen partial pressure in the alumina tube was established by mixing nitrogen and argon. This mixed gas was purified by the same way in quench method and was introduced into the alumina tube from its lower end. Furthermore, the alumina tube was filled with nitrided titanium sponges in its lower part and was lined by nitrided titanium mesh to minimize the oxygen content of the atmosphere in the tube. Since no weight gain was detected in oxidizing $\mathrm{Fe}$ powder at $1300^{\circ} \mathrm{C}$ in this atmosphere, it could be confirmed that the very low oxygen content $\left(P_{\mathrm{O}_{2}}<\right.$ $\left.10^{-10} \mathrm{~atm}\right)$ was established.

\subsection{Quench method}

\section{Results}

Four nitride phases, $\beta-\mathrm{Nb}_{2} \mathrm{~N}, \gamma-\mathrm{Nb}_{4} \mathrm{~N}_{3}, \delta$ - $\mathrm{NbN}$ and $\varepsilon-\mathrm{NbN}$, were existed in quenched samples. Figure 1 shows the regions of experimental conditions in which each phase was formed. Many samples quenched from various annealing temperatures and $P_{\mathrm{N}_{2}}$ consisted of $\gamma$ - and $\delta$-phase, and their composition ranged over $\mathrm{NbN}_{0.71}-\mathrm{NbN}_{0.84}$ and $\mathrm{NbN}_{0.84}-\mathrm{NbN}_{0.92}$ respectively. When $P_{\mathrm{N}_{2}}$ was lower than about $0.05 \mathrm{~atm}$ at $1700^{\circ} \mathrm{C}$ or about $0.025 \mathrm{~atm}$ at $1600^{\circ} \mathrm{C}, \beta$-phase was formed. On the other hand, when $P_{\mathrm{N}_{2}}$ was higher than about $0.15 \mathrm{~atm}$ at

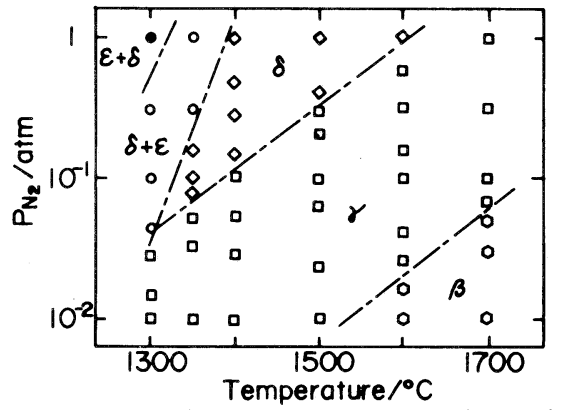

Fig. 1. Relations between experimental conditions and phases formed. $1350^{\circ} \mathrm{C}$ or about 0.025 atm at $1300^{\circ} \mathrm{C}, \varepsilon$-phase coexisted with $\delta$-phase. On the basis of the phase rule, it must not be allowed that two solid phases coexist under various $P_{\mathrm{N}_{2}}$ at one temperature. This is caused by non-equilibrium and its reason will be discussed in section 4.2. The sample prepared at $1300^{\circ} \mathrm{C}$ under $P_{\mathrm{N}_{2}} 1$ atm consisted of $\varepsilon$-phase with trace of $\delta$-phase. The composition of this sample was $\mathrm{NbN}_{0.99}$.

Figure 2 shows the $P_{\mathrm{N}_{2}}-x$ ( $x$ means N/Nb molar ratio) isotherms of $\gamma$ - and $\delta$-phase for temperatures in the range $1300^{\circ}-1700^{\circ} \mathrm{C}$. The compositions $(x)$ were essentially same for samples prepared from the nitride and hydride.

The lattice parameter of $\left.\gamma-\mathrm{Nb}_{4} \mathrm{~N}_{3}{ }^{*}\right)$ and $\delta$ - $\mathrm{NbN}$ is shown in Fig. 3 as a function of composition. The $a$-axis of $\delta$-phase changed linearly with composition. When $x$ in $\mathrm{NbN}_{x}$ became smaller than 0.84 , cubic lattice of $\delta$-phase was distorted to tetragonal lattice of $\gamma$-phase such that two of $a$-axes were extended and another was shortened. The $a$-axis of $\gamma$-phase scarcely changed with composition but the $c$-axis was shortening with

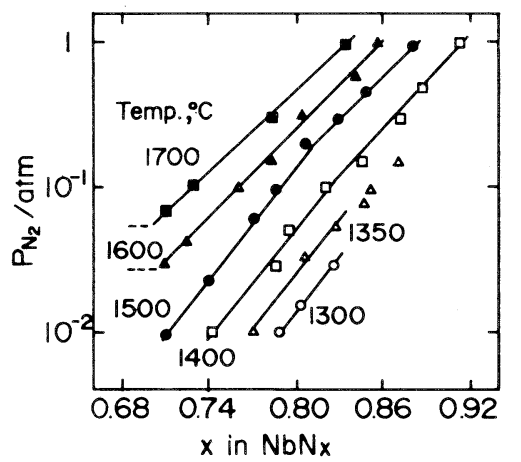

Fig. 2. $P_{\mathrm{N}_{2}}-x$ isotherms in the system $\mathrm{Nb}-\mathrm{N}$ by means of quench method.

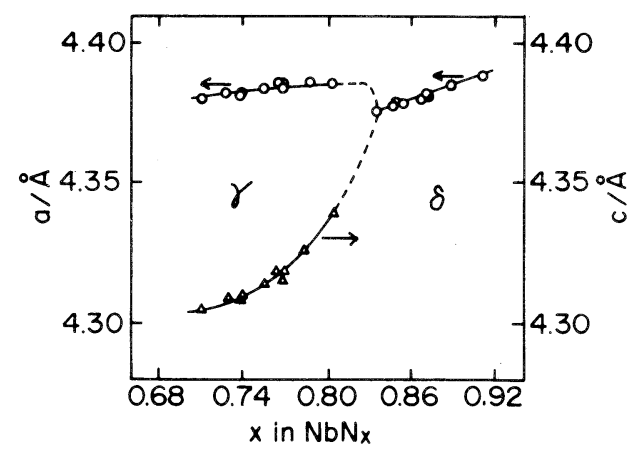

Fig. 3. Lattice parameter of $\gamma-\mathrm{Nb}_{4} \mathrm{~N}_{3}$ and $\delta$ - $\mathrm{NbN}$ as a function of composition.

* The lattice parameter of $\gamma$-phase was calculated regardless of the superstructure discussed in Refs. 6 and 11. 
decreasing nitrogen content. In the composition range between $\mathrm{NbN}_{\mathbf{0 . 8 0}}$ and $\mathrm{NbN}_{\mathbf{0 . 8 4}}$, the separation of adjacent diffraction peaks of $\gamma$-phase, e.g. (200) and (002), was not so clear that the lattice parameter could not be determined.

\section{2 TG method}

Since the results of quench method at $1300^{\circ}$ and $1350^{\circ} \mathrm{C}$ in high $P_{\mathrm{N}_{2}}$ region seemed to have some problems as described in section 3.1, this range was examined also by means of $\mathrm{TG}$ technique. $P_{\mathrm{N}_{2}}-x$ isotherms for $1300^{\circ}$ and $1350^{\circ} \mathrm{C}$ are shown in Fig. 4 with the results of quench method. The annealing time taken to equilibrate the sample after changing $P_{\mathrm{N}_{2}}$ was generally about $20 \mathrm{~h}$.

\section{$4.1 \quad \gamma-\delta$ boundary}

\section{Discussion}

Figure 5 represents $P_{\mathrm{N}_{2}}-T-x$ diagram constructed from Figs. 2 and 4. The isotherms are almost linear but those for the temperatures $1300^{\circ}-1500^{\circ} \mathrm{C}$ changed their slopes slightly at the point shown by dash-dotted line. It is considered on the basis of Fig. 1 that this line is the phase boundary between $\gamma$ - and $\delta$-phase, and that its right-hand side is $\delta$-phase region and the opposite side is $\gamma$-phase region. The absence of distinct

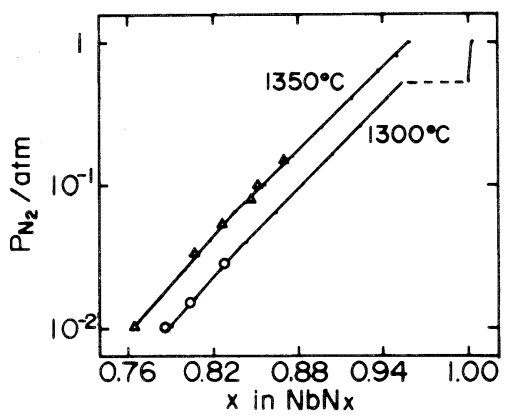

Fig. 4. $\quad P_{\mathrm{N}}-x$ isotherms in the system $\mathrm{Nb}-\mathrm{N}$ by means of $\mathrm{TG}$ method. The results by quench method $(O, \Delta)$ is also shown.

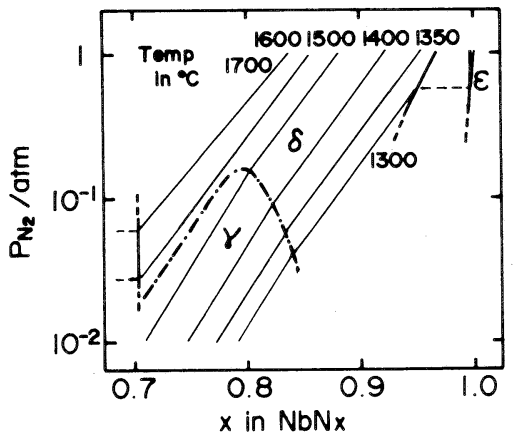

Fig. 5. Representation of $P_{\mathrm{N}_{2}}-x$ isotherms in the system $\mathrm{Nb}-\mathrm{N}$. break on isotherms at these points may suggest that there is not two phase coexisting region of $\gamma$ and $\delta$-phase, that is, the transformation is not first order.

On the other hand, there is no bend on the isotherm for $T=1600^{\circ}-1700^{\circ} \mathrm{C}$. This can be explained that $\gamma$-phase transforms to $\delta$-phase at temperatures between $1500^{\circ}$ and $1600^{\circ} \mathrm{C}$ and $\delta$ phase is stable over composition range $\mathrm{NbN}_{0.71}-\mathrm{NbN}_{0.85}$ above this temperature, since the slopes of these isotherms are similar to those for $T=1300^{\circ}-1500^{\circ} \mathrm{C}$ in $\delta$-phase region and Christensen's work using high temperature X-ray analysis ${ }^{9)}$ noted that $\gamma$-phase transformed to $\delta$-phase at temperatures between $1550^{\circ}$ and $1660^{\circ} \mathrm{C}$.

It is found from these considerations and the result shown in Fig. 1 that $\delta$-phase with the composition $\mathrm{NbN}_{\mathbf{0 . 7 1}}-\mathrm{NbN}_{\mathbf{0 . 8 4}}$ transformed to $\gamma$ phase without compositional change during quenching. The transformation $\gamma \rightleftarrows \delta$ is an orderdisorder transformation and considered to occur rapidly. However, $\delta$-phase with the composition $\mathrm{NbN}_{\mathbf{0 . 8 4}}-\mathrm{NbN}_{0.92}$ seemed to take place no transformation during quenching. The phenomenological difference between cases described above can be explained as follows. $\delta$-phase with the composition $\mathrm{NbN}_{0.84}-\mathrm{NbN}_{0.92}$ must be changed its composition in order to transform to $\gamma$-phase because the nitrogen saturated limit of $\gamma$-phase is $\mathrm{NbN}_{\text {0.84 }}$. Therefore, transformation $\delta \rightarrow \gamma$ becomes slow and cannot occur practically in this composition range.

\section{4. $2 \delta-\varepsilon$ boundary}

As mentioned above, samples quenched from temperatures $1300^{\circ}-1350^{\circ} \mathrm{C}$ under relatively high $P_{\mathrm{N}_{2}}$ consisted of $\delta$ - and $\varepsilon$-phase. In general, such phenomenon is often observed when the transformation tends to ocuur during quenching. However in this case, this interpretation is not valid because the samples quenched from higher temperatures, e.g. at $1400^{\circ} \mathrm{C}$ under $P_{\mathrm{N}_{2}}=1$ atm, consisted of $\delta$-phase without $\varepsilon$-phase. Another possible reason is that small content of $\varepsilon$-phase in $\delta$-phase retained as a metastable state especially at the conditions in the vicinity of phase boundary and was difficult to transform. Trace of $\delta$-phase in the sample quenched from $1300^{\circ} \mathrm{C} 1$ atm could be explained by similar reason. Nevertheless, this must be confirmed by high temperature X-ray analysis.

The linear isotherms of $1300^{\circ}$ and $1350^{\circ} \mathrm{C}$ in Fig. 4 by means of $T G$ method suggest that 
$\delta$-phase is stable up to $P_{\mathrm{N}_{2}}=1$ atm at $1350^{\circ} \mathrm{C}$ and $P_{\mathrm{N}_{2}}=0.5 \mathrm{~atm}$ at $1300^{\circ} \mathrm{C}$. The break on the isotherm for $1300^{\circ} \mathrm{C}$ corresponds to transformation $\delta \rightleftarrows \varepsilon$. Since the composition of $\delta$-phase at this point, about $\mathrm{NbN}_{0.95}$, is somewhat smaller than that of the sample prepared at $1350^{\circ} \mathrm{C}$ under $P_{\mathrm{N}_{2}}=$ $1 \mathrm{~atm}$, the nitrogen saturated limit of $\delta$-phase region probably extends to larger nitrogen content with increasing temperature.

The region of $\varepsilon$-phase cannot be well confirmed, but the homogeneity range of this phase is considered to be narrow.

\section{4. $3 \delta-\beta$ and $\gamma-\beta$ boundaries}

The breaks on the isotherms for $1600^{\circ}-1700^{\circ} \mathrm{C}$ shown by broken line in Fig. 5 correspond to the transformation $\delta \rightleftarrows \beta$. The niobium saturated limit of $\delta$-phase region is about $\mathrm{NbN}_{0.71}$ above $1600^{\circ} \mathrm{C}$; and that of $\gamma$-phase region could not be determined but expected to be same as of $\delta$ phase.

The region of $\beta$-phase is not investigated in this experiment.

\section{4 phase diagram}

On the basis of these results and the data of previous workers, phase diagram for temperatures $1200^{\circ}-1700^{\circ} \mathrm{C}$ is proposed in Fig. 6. This diagram

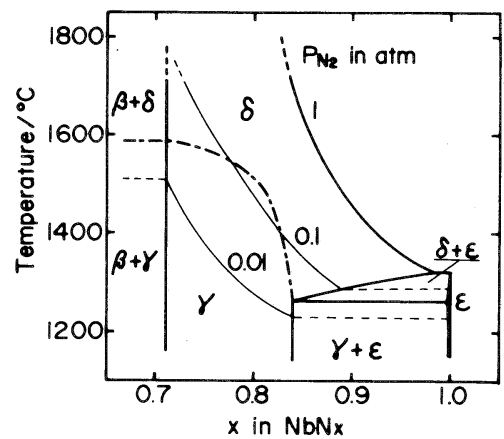

Fig. 6. Proposed phase diagram of the system $\mathrm{Nb}-\mathrm{N}$. is different from that of Guard et al. ${ }^{5)}$ at some points. The two phases coexisting region of $\gamma$ and $\delta$-phase is wide in their diagram but is not present in our result. Further, the homogeneity ranges of $\gamma$-and $\delta$-phase are considerably wider compared with their data. These differences can be mainly caused by the difference of experimental procedure. Their investigation was carried out by metallographic and X-ray diffraction technique for quenched sample and was not sufficient to examine the phase relations at high temperature.

Nevertheless, $P-T-x$ diagram is not always best to study high temperature equilibrium so that there remains a few questions, e.g. temperature of and order of transformation $\gamma \rightleftarrows \delta$. To make these questions clear, in situ experiment such as high temperature X-ray analysis will be required.

\section{References}

1) G. Brauer and J. Jander, Z. Anorg. Allgem. Chem., 270, 160-78 (1952).

2) N. Schönberg, Acta Chem. Scand., 8, 208-12 (1954).

3) G. Brauer and R. Esselborn, Z. Anorg. Allgem. Chem., 309, 151-70 (1961).

4) G. Brauer and H. Kirner, Z. Anorg. Allgem. Chem., 328, 34-43 (1964).

5) R.W. Guard, J.W. Savage and D.G. Swarthout, Trans. AIME, 239, 643-49 (1967).

6) N. Terao, Japan. J. Appl. Phys, , 47, 2833-40 (1965).

7) N. Terao, J. Less-Common Met., 23, 159-69 (1971).

8) G. Oya and Y. Onodera, J. Appl. Phys., 47, 2833-40 (1976).

9) A. N. Christensen, Acta Chem. Scand., A 30, 219-24 (1976).

10) G. Heger and O. Baumgartner, J. Phys., C 13, 5833-41 (1980).

11) A. N. Christensen, R. G. Hazell and M.S. Lehmann, Acta Chem. Scand., A 35, 111-15 (1981).

12) L. E. Toth, "Transition Metal Carbides and Nitrides", Academic Press (1971) p. 91.

13) E. Gebhardt, E. Fromm and D. Jakob, Z. Metallkde., 55, 423-31 (1964).

14) N. Kieda, K. Uematsu, N. Mizutani and M. Kato, J. Less-Common Met., 99, 131-35 (1984). 